\title{
Meat Quality of Guinea Pig (Cavia porcellus) Fed with Black Soldier Fly Larvae Meal (Hermetia illucens) as a Protein Source
}

\author{
Esteban Herrera ${ }^{1} @$, Janos-Istvan Petrusan ${ }^{2, *}{ }^{\circledR}$, Bettit Salvá-Ruiz ${ }^{1}\left(\mathbb{D}\right.$, Alexandra Novak $^{1}$, Kenyi Cavalcanti $^{3}{ }^{\circledR}$, \\ Víctor Aguilar $^{3}{ }^{-1}$, Volker Heinz ${ }^{2}$ and Sergiy Smetana ${ }^{2}{ }^{\mathbb{D}}$ \\ 1 Departamento de Tecnología de los Alimentos y Productos Agropecuarios, Facultad de Industrias \\ Alimentarias, Universidad Nacional Agraria La Molina, Av. la Molina s/n, Lima 15024, Peru; \\ estebangabrielhn@gmail.com (E.H.); bsalva@lamolina.edu.pe (B.S.-R.); anovak@fumiguerra.com (A.N.) \\ 2 German Institute of Food Technologies (DIL e.V.), Prof.-von-Klitzing-Str. 7 D, 49610 Quakenbrück, Germany; \\ v.heinz@dil-ev.de (V.H.); s.smetana@dil-ev.de (S.S.) \\ 3 Departamento Académico de Ordenamiento Territorial y Construcciòn, Facultad de Ingeniería Agrícola, \\ Universidad Nacional Agraria La Molina, Av. la Molina s/n, Lima 15024, Peru; \\ kcavalcanti@lamolina.edu.pe (K.C.); vaguilar@lamolina.edu.pe (V.A.) \\ * Correspondence: j.petrusan@dil-ev.de
}

check for

updates

Citation: Herrera, E.; Petrusan, J.-I.; Salvá-Ruiz, B.; Novak, A.; Cavalcanti, K.; Aguilar, V.; Heinz, V.; Smetana, S. Meat Quality of Guinea Pig (Cavia porcellus) Fed with Black Soldier Fly Larvae Meal (Hermetia illucens) as a Protein Source. Sustainability 2022, 14, 1292. https://doi.org/10.3390/ su14031292

Academic Editor: Massimo Lucarini

Received: 30 November 2021

Accepted: 19 January 2022

Published: 24 January 2022

Publisher's Note: MDPI stays neutral with regard to jurisdictional claims in published maps and institutional affiliations.

Copyright: (c) 2022 by the authors. Licensee MDPI, Basel, Switzerland. This article is an open access article distributed under the terms and conditions of the Creative Commons Attribution (CC BY) license (https:// creativecommons.org/licenses/by/ $4.0 /)$.

\begin{abstract}
The most widely used feed ingredients in the world are fishmeal and soybean, which, despite having high-quality digestible protein and good fat content, are considered environmentally unsustainable and increasingly expensive. This issue also involves the guinea pig, a very important animal protein source for people in Andean regions in South America. Here we investigate the substitution of soybean meal with $50 \%$ and $100 \%$ black soldier fly larvae meal in the guinea pig diet and its effects on meat quality (fatty acid profile, amino acid profile, water-holding capacity, $\mathrm{pH}$, proximal composition, and color). The results showed no differences in the protein content and amino acid profile of meat nor in the n-6:n-3 and P/S ratios, but did show an increment in the desirable fats (mono- and polyunsaturated fatty acids) in the guinea pigs fed with black soldier fly larvae meal. All the other analyzed parameters showed no differences among the diets tested. These results suggest that total replacement of soybean meal with black soldier fly larvae meal in guinea pig nutrition is feasible since meat quality was maintained or improved.
\end{abstract}

Keywords: insects; fatty acids; amino acids; soybean; sustainable; feed

\section{Introduction}

There is increasing concern about using soybean meal in feed due to its environmental impacts and poor sustainability, which has led researchers to assess alternatives for animal nutrition [1-3]. In this context, insects are recognized as a good source of proteins due to their balanced essential amino acid profile [4] and have been suggested as an alternative for meat [5-8] and feed [9]. In particular, the black soldier fly (Hermetia illucens) has been suggested as a more sustainable alternative as feed, without compromising performance parameters in animal rearing [10-13] thanks to its high levels of proteins (37-63\% dry matter basis) and fat (up to $49 \%$ ), as well as several macro and micronutrients, which are important for animal development [14] [15-18]. Therefore, many studies remark the possibility of replacing the increasingly expensive protein sources commonly employed such as fishmeal and soybean meal $[19,20]$. Moreover, H. illucens insect biomass seems to have specific antimicrobial properties [21,22], which creates unique potential for the application in the industry as a feed additive. Recent studies highlight the benefits of the use of H. illucens as a particularly useful feed for pigs [23-25], chickens [26,27], and fish [12] Although several studies have assessed the benefits of black soldier fly larvae meal as feed, most of them are focused on growth performance and few analyzed the amino acid and fatty acid profile of the meat. Furthermore, there is a lack of research on insect use 
as feed for regionally important animals in South America, and to the best knowledge of the authors, no studies reflect the environmental impact of guinea pigs' production. While animals such as guinea pigs (Cavia porcellus) are not intended for global mass production, they play an important economic, social, and cultural role for Andean communities [28]. The guinea pigs fulfil a very important function, reducing the protein deficit and providing economic incomes [29]. Hence, this study aimed to assess the benefits of H. illucens larvae as feed for guinea pigs and its impact on meat quality.

\section{Materials and Methods}

The study was carried out in a commercial farm in Cieneguilla (Lima, Peru). Rearing conditions including animal welfare were in accordance with the Peruvian Ministry of Agriculture guidelines and also comply with the ARRIVE guidelines and were carried out in accordance with the U.K. Animals (Scientific Procedures) Act, 1986 and associated guidelines, EU Directive 2010/63/EU for animal experiments. The animals were stunned and slaughtered following the previously reported method [29] by cutting the jugular vein. After exsanguination, the animals were introduced into boiling water for $1 \mathrm{~min}$ and manually dehaired, where the last operation was repeated until the total removal of hair. Animals were finally eviscerated and stored in ice for $8 \mathrm{~h}$ until analyses.

\subsection{Experimental Design}

Sixty male guinea pigs (C. porcellus) from the Peru strain, recently weaned (ca. 21 days of age; average weight: $0.30 \pm 0.01 \mathrm{~kg}$ ), were selected and divided into three different feed groups (T0, T1, and T2, explained below) of twenty animals each by simple randomization. In each group, the twenty guinea pigs were divided in four groups of five animals each. Grouped animals were housed in ground pens of $1 \mathrm{~m}^{2}$ at an average temperature of $21^{\circ} \mathrm{C}$ with $45 \%$ humidity. The 12 groups were distributed in a single row by simple randomization to avoid bias due to position order.

\subsection{Experimental Diets}

Three different diets were formulated according to the standard guinea pig nutritional requirements [30,31] and consisted of concentrate and maize forage. A concentrate formula was based on a commercial product for guinea pigs of a local company. While forage was the same for the 3 different feed groups, regarding concentrate, the only variation in the formula was focused on the substitution of soybean meal: In T0, the control diet, soybean meal was the main protein source; in T1, soybean meal was substituted by $50 \%$ black soldier fly (BSF) larvae meal; in T2, soybean meal was 100\% substituted with black soldier fly (BSF) larvae meal. Thus, soybean meal content was $15 \% w / w$ in T0, $7.5 \%$ in $\mathrm{T} 1$, and $0 \%$ in $\mathrm{T} 2$, while all the other ingredients of concentrate were maintained constant (corn, bran, soy oil, molasses, calcium, salt, methionine, lysine, choline chloride, mineral vitamin premix). The quantity of soybean meal in concentrate formulations was calculated considering only the protein quantity of such meal, and its replacement with black soldier fly meal was calculated by weight. Therefore, the proximal composition could be different in experimental diets, especially fat content, due to differences between defatted soybean meal and whole black soldier fly larvae meal. The proximate composition and amino acid profile of experimental diets were analyzed, and the results are shown in Table 1. The black soldier fly (H. Illucens) larvae meal was provided by the Universidad Catolica de Santa Maria (Arequipa, Peru) and the soybean meal was acquired from a random commercial market. The BSF larvae were dried using a conventional tunnel dryer with hot air $\left(105^{\circ} \mathrm{C} \times 30 \mathrm{~min}\right)$ until $8 \%$ moisture content was reached, and was then grinded, before being incorporated into the concentrates. 
Table 1. Proximate composition and amino acid profile of experimental diets: T0: Control diet, T1: $50 \%$ substitution with BSF meal; T2: $100 \%$ substitution with BSF meal.

\begin{tabular}{|c|c|c|c|}
\hline Proximate Composition & T0 & T1 & T2 \\
\hline Energy (Kcal in $100 \mathrm{~g})$ & 351.5 & 355.2 & 360.6 \\
\hline$\%$ Kcal from fat & 15.1 & 17.2 & 19.5 \\
\hline$\%$ Kcal from protein & 18.4 & 17.1 & 18.3 \\
\hline$\%$ Kcal of carbohydrates & 66.5 & 65.7 & 62.2 \\
\hline Carbohydrates (\%) & 58.4 & 58.3 & 56.1 \\
\hline Protein $(\%)$ & 16.2 & 15.2 & 16.5 \\
\hline Fat $(\%)$ & 5.9 & 6.8 & 7.8 \\
\hline Ash (\%) & 5.5 & 5.9 & 5.8 \\
\hline Moisture (\%) & 14.0 & 13.8 & 13.8 \\
\hline \multicolumn{4}{|c|}{ Amino acids (g/100 g protein) } \\
\hline Aspartic acid & 9.60 & 9.14 & 8.28 \\
\hline Glutamic acid & 18.76 & 16.67 & 15.30 \\
\hline Serine & 5.67 & 5.26 & 5.01 \\
\hline Glycine & 4.36 & 4.46 & 4.94 \\
\hline Histidine & 2.55 & 2.49 & 2.16 \\
\hline Threonine & 4.95 & 5.34 & 4.24 \\
\hline Alanine & 2.91 & 2.85 & 2.99 \\
\hline Arginine & 10.25 & 11.11 & 12.73 \\
\hline Proline & 6.91 & 6.80 & 7.02 \\
\hline Tyrosine & 3.27 & 3.80 & 4.45 \\
\hline Valine & 4.73 & 5.26 & 5.63 \\
\hline Methionine + Cysteine & 2.69 & 2.78 & 2.78 \\
\hline Leucine & 4.44 & 4.68 & 5.01 \\
\hline Lysine & 6.98 & 7.24 & 6.82 \\
\hline Isoleucine & 5.09 & 5.12 & 5.15 \\
\hline Phenylalanine & 5.67 & 5.70 & 6.26 \\
\hline Tryptophan & 1.16 & 1.32 & 1.25 \\
\hline
\end{tabular}

\subsection{Fattening of Guinea Pigs}

The fattening of guinea pigs started immediately after weaning and was carried out for 13 weeks according to Lammers et al. (2009). During fattening, each guinea pig received $150 \mathrm{~g}$ of maize forage and $50 \mathrm{~g}$ of experimental concentrate daily. All guinea pigs were slaughtered in the same place as rearing to minimize stress due to transport and handling that could affect $\mathrm{pH}$ values, water-holding capacity, and color.

\subsection{Water-Holding Capacity, $\mathrm{pH}$, and Color}

Skin, bones, viscera, and under-skin fat were removed from guinea pigs before analyses. Meat color was measured using a Konica Minolta Chroma meter CR-400 (CIELab space color) in the rectus abdominis. Color measures were taken in the CIE L*a* $\mathrm{b}^{*}$ color space (illuminant: D65; visual angle: 10; SCI mode; 11- $\mathrm{mm}$ aperture for illumination and $8 \mathrm{~mm}$ for measurement; chromometer was calibrated with the white calibration tile provided with the equipment), as previously described by Honikel [32]. $\mathrm{pH}$ was measured using an SI Analytics HandyLab 100 portable $\mathrm{pH}$ meter in the longissimus thoracis et lumborum muscle; 
the water-holding capacity (WHC) was measured through the weight difference in meat after pressing the biceps femoris and expressed as the percentage of fluid retained. Briefly, $300 \mathrm{mg}$ of the meat sample was weighed, placed over a previously weighed Whatman no. 1 filter paper (Whatman International Ltd., Kent, UK), and pressed between two rigid plastic plates, using a $1.000 \mathrm{~kg}$ weight, for $5 \mathrm{~min}$. WHC, $\mathrm{pH}$, and color were measured $8 \mathrm{~h}$ after slaughtering. Right after these analyses were finished, meat samples were immediately frozen and stored at $-18{ }^{\circ} \mathrm{C}$ for 2 weeks.

Prior to the proximate composition, amino acids, and fatty acids analyses, guinea pig meat samples were defrosted and homogenized. The homogenization was carried out using a grinder (Mainca ${ }^{\circledR}$, model PM-70, Granollers, Spain) and a food cutter (Hobart ${ }^{\circledR}$, model 84145, Troy, MI, USA).

\subsection{Proximate Composition of Meat}

Moisture was measured according to the AOAC 950.46 method; protein was measured according to the AOAC 928.08 method; fat was measured according to the AOAC 960.39 method; ashes were measured according to the AOAC 920.153 method [33]. Carbohydrates were calculated as 100-ash (\%)-fat (\%)-protein (\%)-moisture (\%).

\subsection{Amino Acids}

The amino acid profiles of guinea pig meat were analyzed using HPLC (Chromaster, Hitachi ${ }^{\circledR}$, Japan) with a fluorescence detector (wavelength was fixed at $254 \mathrm{~nm}$ ) and a reversed-phase column $(300 \times 3.9 \mathrm{~mm}$, pore size $60 \AA$, Novapack Ci8, $4 \mathrm{j}$, Waters $)$ according to the method described by Heinrikson and Meredith [34], using (A) Sodium acetate $25 \mathrm{mM}-0.02 \% \mathrm{NaOH}$ and (B) Acetonitrile as solvents. The gradient was set as follows: 0-3 min linear gradient A:B (91:9) to A:B (86:14), 3-13 min A:B (86:14), 13-30 min linear gradient A:B (86-14) to (69:31), 30-35 min A:B (69:31). Samples were previously hydrolyzed with $\mathrm{HCl} 6 \mathrm{~N}$ for $24 \mathrm{~h}$ at $100{ }^{\circ} \mathrm{C}$, and then derivatization was performed using Diethyl ethoxymethylenemalonate. For identification and quantitation, an external standard mix of analytical-grade amino acids from Sigma Aldrich was used. The mix contained Alanine, Arginine, Aspartic Acid, Cysteine, Glutamic Acid, Glycine, Histidine, Isoleucine, Leucine, Lysine, Methionine, Phenylalanine, Proline, Serine, Threonine, Tyrosine, and Valine.

\subsection{Fatty Acids}

Fat from meat samples (100 g) was extracted with chloroform $(100 \mathrm{~mL})$, methanol $(200 \mathrm{~mL})$, and water $(100 \mathrm{~mL})$. The extract was then filtered using Whatman $\mathrm{N}^{\circ} 1$, transferred into a separatory funnel for $3 \mathrm{~h}$, and filtered with Whatman $\mathrm{N}^{\circ} 41$ and washed with $5 \mathrm{~g}$ of sodium sulfate (to remove water). After extraction, $50 \mathrm{mg}$ of the fat sample was treated with $2.5 \mathrm{~mL}$ of petroleum ether, and saponification and methylation were performed using $0.25 \mathrm{~mL}$ of sodium hydroxide $2 \mathrm{~N}$ in methanol and then neutralized with $0.3 \mathrm{~mL}$ of hydrochloric acid $2 \mathrm{~N}$ in methanol. The fatty acid profile was then analyzed according to AOAC 996.06 using a GC (Autosystem XL, Perkin Elmer, Waltham, MA, USA) with a flame ionization detector (FID) and a $30 \mathrm{~m} \times 0.25 \mathrm{~mm} \times 0.25 \mu \mathrm{m}$ Spelcowax-10 column (Supelco, SigmaAldrich, Saint-Louis, MO, USA). Fatty acid external standards (Sigma Aldrich) were used for quantification. The oven temperature was set from $160^{\circ} \mathrm{C}$ to $230{ }^{\circ} \mathrm{C}$ in $65 \mathrm{~min}$, split mode 100:1, with a $2 \mu \mathrm{L}$ injection volume and hydrogen as the carrier gas.

\subsection{Statistical Analyses}

To analyze differences between treatments, ANOVA and Kruskal-Wallis tests were performed according to the normality of the regression residuals between the variables. Normality was assessed by Kolgomorov-Smirnov and Shapiro-Wilk tests, whilst homoscedasticity was assessed by Levene's test. Those variables that showed heteroscedasticity were analyzed using Welch's robust test of equality of means. The post hoc analysis was performed to analyze the specific differences between treatments: In data showing normality, using the Tukey SD, and in the case of no normality, using the Mann-Whitney U tests with 
the correction of Benjamini and Hochberg [35]. All statistical analyses were carried out using Statgraphics Centurion 18 software and the free software R version 4.0.2.

\subsection{Sustainability Aspects}

The sustainability aspects in the study included the environmental impact analysis via Life Cycle Assessment (LCA) to define the environmental impact of guinea pigs' production with and without the inclusion of insects in the feed. An attributional LCA approach was chosen, which allowed for the identification of the comparative effect of different production settings in the same "cradle-to-gate" boundaries. Considering the similarities in the nutritional properties of $C$. porcellus, the functional unit (FU) in the study relied on the mass and economic value for the identification of impact allocation. As a basis, the FU mass of products $(1 \mathrm{~kg}$ ) was used in the assessment. LCA was performed for the conditions of Peru, based on the inventory collected directly during the trials, and we relied on SimaPro 9.0.2 software (PRè Consultants, The Netherlands) and the impact assessment method IMPACT 2002+ (V 2.11) [36] selected for a combined midpoint-endpoint damage-oriented approach [37].

\section{Results}

Guinea pigs of all the three treatments (T0, T1, and T2) were slaughtered after 13 weeks and no significant difference in weight was found (in average $1.0 \pm 0.1 \mathrm{~kg}$ ). Skin, viscera, and under-skin fat were removed before analyses mainly due to the traditional consumption of guinea pigs not taking into consideration those components. The water-holding capacity, $\mathrm{pH}$, and color were measured in muscles after slaughtering. The proximate composition, amino acids, and fatty acids were analyzed after homogenization of samples.

\subsection{Water-Holding Capacity, $\mathrm{pH}$ and Color}

The results (Table 2) showed that the diet did not significantly impact the guinea pig meat water-holding capacity (on average $74.5 \%$ ), $\mathrm{pH}$ (on average 5.9 ), or color ( $\mathrm{L}^{*}$ on average 46.3 , a* on average $10.6, b^{*}$ on average 1.1 ).

Table 2. Water-holding capacity, $\mathrm{pH}$, and color of guinea pig (Cavia porcellus) meat fed with: T0: Control diet, T1: 50\% substitution with BSF meal; T2: 100\% substitution with BSF meal.

\begin{tabular}{lccc}
\hline \multicolumn{1}{c}{ Parameter } & T0 & T1 & T2 \\
\hline Water Holding capacity (WHC) & $74.15 \pm 1.02^{\mathrm{a}}$ & $75.73 \pm 1.09^{\mathrm{a}}$ & $73.59 \pm 1.09^{\mathrm{a}}$ \\
\hline $\mathrm{pH}$ & $5.91 \pm 0.03^{\mathrm{a}}$ & $5.93 \pm 0.04^{\mathrm{a}}$ & $5.87 \pm 0.03^{\mathrm{a}}$ \\
\hline $\mathrm{COLOUR}$ & & & \\
\hline $\mathrm{L}^{*}$ (luminosity) & $46.42 \pm 0.46^{\mathrm{a}}$ & $46.07 \pm 0.47^{\mathrm{a}}$ & $46.34 \pm 0.40^{\mathrm{a}}$ \\
\hline $\mathrm{a}^{*}$ (red- green) & $10.52 \pm 0.28^{\mathrm{a}}$ & $10.99 \pm 0.43^{\mathrm{a}}$ & $10.38 \pm 0.40^{\mathrm{a}}$ \\
\hline $\mathrm{b}^{*}$ (blue- yellow) & $1.00 \pm 0.45^{\mathrm{a}}$ & $1.62 \pm 0.38^{\mathrm{a}}$ & $0.76 \pm 0.40^{\mathrm{a}}$ \\
\hline
\end{tabular}

Note: Values are mean \pm standard error $(n=20)$. For each parameter, different letters denote statistical differences $(p<0.05)$ according to Kruskal-Wallis test. WHC was analyzed in rectus abdominis muscle, $\mathrm{pH}$ was analyzed in Longissimus thoracis et lumborum, color was measured on biceps femoris muscle.

\subsection{Proximate Composition}

The different diets used to feed the guinea pigs showed no impact on the final proximate composition of the meat (Table 3). All treatments showed similar values of moisture $(73 \%)$, proteins $(18 \%)$, and fat $(7.5 \%)$. 
Table 3. Proximate composition of guinea pig (Cavia porcellus) meat under different feeding diets: T0: Control diet, T1: 50\% substitution with BSF meal; T2: 100\% substitution with BSF meal.

\begin{tabular}{lccc}
\hline \multicolumn{1}{c}{ Proximate Composition } & T0 & T1 & T2 \\
\hline Protein $(\%)$ & $17.80 \pm 0.18^{\mathrm{a}}$ & $18.08 \pm 0.23^{\mathrm{a}}$ & $18.23 \pm 0.15^{\mathrm{a}}$ \\
\hline Fat $(\%)$ & $7.78 \pm 0.09^{\mathrm{a}}$ & $7.35 \pm 0.29^{\mathrm{a}}$ & $6.43 \pm 0.13^{\mathrm{a}}$ \\
\hline Moisture (\%) & $72.88 \pm 0.20^{\mathrm{a}}$ & $72.88 \pm 0.15^{\mathrm{a}}$ & $73.35 \pm 0.28^{\mathrm{a}}$ \\
\hline Ash $(\%)$ & $1.08 \pm 0.05^{\mathrm{a}}$ & $1.33 \pm 0.06^{\mathrm{a}}$ & $1.15 \pm 0.05^{\mathrm{a}}$ \\
\hline
\end{tabular}

Note: Values are means of quadruplicate \pm standard error $(\mathrm{N}=4)$. Different letters $(\mathrm{a}, \mathrm{b})$ in the same row indicate significant differences at $(p<0.05)$ according to Kruskal-Wallis test.

\subsection{Amino Acids}

The amino acid profiles of the three diets tested (T0, T1, and T2) were very similar (Table 1). Correspondingly, no significant differences were found in the amino acid profiles of meats from the different treatments (T0, T1, and T2) (Table 4). Guinea pig meat had all nine essential amino acids (Table 5), and among them, the highest value was recorded for Leucine (on average, $8.1 \mathrm{~g} / 100 \mathrm{~g}$ of protein) and the lowest for Tryptophan (on average, $1 \mathrm{~g} / 100 \mathrm{~g}$ of protein).

Table 4. Amino acid profile of guinea pig (Cavia porcellus) meat under different feeding diets: T0balanced feed with $100 \%$ protein supply from soybean meal, $\mathrm{T} 1$ - balanced feed with $50 \%$ protein supply from soybean meal and 50\% from H. illucens larvae meal; T2-balanced feed with $100 \%$ protein supply from H. illucens larvae meal.

\begin{tabular}{|c|c|c|c|}
\hline Amino Acid & T0 (g/100 g Protein) & T1 (g/100 g Protein) & T2 (g/100 g Protein) \\
\hline Aspartic acid & $9.76 \pm 0.12^{\mathrm{a}}$ & $9.78 \pm 0.01^{\mathrm{a}}$ & $9.71 \pm 0.11^{\mathrm{a}}$ \\
\hline Glutamic acid & $15.20 \pm 0.16^{\mathrm{a}}$ & $15.24 \pm 0.09^{\mathrm{a}}$ & $14.69 \pm 0.18^{\mathrm{a}}$ \\
\hline Serine & $4.48 \pm 0.02^{\mathrm{a}}$ & $4.48 \pm 0.02^{\mathrm{a}}$ & $4.36 \pm 0.01^{\mathrm{a}}$ \\
\hline Glycine & $6.80 \pm 0.25^{a}$ & $5.90 \pm 0.18^{a}$ & $6.60 \pm 0.36^{a}$ \\
\hline Histidine & $2.26 \pm 0.03^{a}$ & $2.25 \pm 0.02^{a}$ & $2.73 \pm 0.04^{\mathrm{a}}$ \\
\hline Threonine & $5.04 \pm 0.34^{\mathrm{a}}$ & $4.54 \pm 0.05^{\mathrm{a}}$ & $4.51 \pm 0.11^{\mathrm{a}}$ \\
\hline Alanine & $3.39 \pm 0.10^{a}$ & $3.57 \pm 0.02^{a}$ & $3.64 \pm 0.04^{a}$ \\
\hline Arginine & $12.32 \pm 0.01^{\mathrm{a}}$ & $12.18 \pm 0.05^{\mathrm{a}}$ & $12.53 \pm 0.02^{\mathrm{a}}$ \\
\hline Proline & $4.98 \pm 0.11^{\mathrm{a}}$ & $4.60 \pm 0.09^{\mathrm{a}}$ & $4.91 \pm 0.19^{\mathrm{a}}$ \\
\hline Tyrosine & $3.45 \pm 0.05^{\mathrm{a}}$ & $3.47 \pm 0.00^{a}$ & $3.45 \pm 0.04^{\mathrm{a}}$ \\
\hline Valine & $4.77 \pm 0.02^{\mathrm{a}}$ & $4.92 \pm 0.03^{a}$ & $4.75 \pm 0.06^{\mathrm{a}}$ \\
\hline $\begin{array}{l}\text { Methionine + } \\
\text { Cysteine }\end{array}$ & $2.75 \pm 0.05^{\mathrm{a}}$ & $2.75 \pm 0.01^{a}$ & $2.66 \pm 0.04^{\mathrm{a}}$ \\
\hline Isoleucine & $4.05 \pm 0.03^{a}$ & $4.40 \pm 0.03^{a}$ & $4.65 \pm 0.04^{a}$ \\
\hline Leucine & $7.71 \pm 0.13^{a}$ & $7.97 \pm 0.10^{\mathrm{a}}$ & $8.54 \pm 0.10^{a}$ \\
\hline Phenylalanine & $4.23 \pm 0.01^{\mathrm{a}}$ & $4.83 \pm 0.08^{a}$ & $4.43 \pm 0.02^{\mathrm{a}}$ \\
\hline Lysine & $7.66 \pm 0.07^{a}$ & $8.18 \pm 0.09^{a}$ & $6.83 \pm 0.13^{a}$ \\
\hline Tryptophan & $1.16 \pm 0.13^{a}$ & $0.92 \pm 0.03^{a}$ & $1.01 \pm 0.06^{\mathrm{a}}$ \\
\hline $\begin{array}{l}\text { otal protein content } \\
\text { (g/100 g of meat) }\end{array}$ & $16.44 \pm 0.68$ & $16.99 \pm 0.31$ & $15.85 \pm 0.45$ \\
\hline
\end{tabular}

Note: Values are means of quadruplicate \pm standard error $(n=4)$. Different letters $(\mathrm{a}, \mathrm{b})$ in the same row are significantly different at $(p<0.05)$ according to Kruskal-Wallis test. 
Table 5. Essential amino acids of commercial meats and guinea pigs fed with black soldier fly larvae (g/100 g protein).

\begin{tabular}{|c|c|c|c|c|c|c|c|}
\hline Amino Acid & $\begin{array}{c}\text { Adults } \\
\text { Requirements }\end{array}$ & $\begin{array}{c}\text { Children } \\
<3 \text { Years } \\
\text { Requirements }\end{array}$ & Beef $^{a}$ & Pork $^{a}$ & Chicken $^{a}$ & Rabbit $^{b}$ & $\begin{array}{c}\text { Guinea } \\
\text { Pig }^{c}\end{array}$ \\
\hline Lysine & 4.8 & 5.7 & 9.1 & 8.4 & 9.6 & 10.4 & 7.6 \\
\hline Histidine & 1.6 & 2.0 & 3.9 & 3.1 & 4.0 & 5.5 & 2.4 \\
\hline Threonine & 2.5 & 3.1 & 4.1 & 4.4 & 5.0 & 5.4 & 4.7 \\
\hline $\begin{array}{l}\text { Methionine } \\
+ \text { Cysteine }\end{array}$ & 2.3 & 2.7 & 4.0 & 3.8 & 4.2 & 3.6 & 2.7 \\
\hline Valine & 4.0 & 4.3 & 4.8 & 6.0 & 5.9 & 5.0 & 4.8 \\
\hline Isoleucine & 3.0 & 3.2 & 4.3 & 5.2 & 4.9 & 4.1 & 4.4 \\
\hline Leucine & 6.1 & 6.6 & 8.6 & 7.8 & 8.4 & 8.1 & 8.1 \\
\hline Phenylalanine. & 4.1 & 5.2 & 7.6 & 5.6 & 7.6 & 7.7 & 8.0 \\
\hline Tryptophan & 0.6 & 0.9 & 1.1 & 0.9 & 1.2 & 1.3 & 1.0 \\
\hline
\end{tabular}

\subsection{Fatty Acids}

The guinea pig diet impacted the fatty acid profile of the meat. In particular, significant differences $(p<0.05)$ were found between T0 (control diet) and T1 $(100 \%$ substitutions with black soldier fly larvae meal) in linoleic acid (C18:2 n6) (on average, an increment of 43\%), linolenic acid (C18:2 n3) (on average, an increment of 42\%), oleic acid (C18:1 n9) (on average, an increment of $54 \%$ ), stearic acid (C18:0) (on average, an increment of $33 \%$ ), and especially palmitic acid (C16:0), palmitoleic acid (C16:1), myristic acid (C14:0), and lauric acid (C12:0), which increased from almost none to $1.68,0.13,0.37$, and $0.36 \mathrm{~g} / 100 \mathrm{~g}$, respectively (Table 6). In general, the introduction of insects to the guinea pig diet determined an increase in the content of fatty acids (a total increase of $32 \%$ and $57 \%$ in polyunsaturated fatty and saturated fatty acids if compared to the control diet, respectively).

Table 6. Fatty acid profile (g/100 g of meat) of guinea pig (C. porcellus) meat under different feeding diets: T0: Control diet, T1: 50\% substitution with BSF meal; T2: 100\% substitution with BSF meal.

\begin{tabular}{ccccc}
\hline & Fatty Acids & T0 (g/100 g FA) & T1 (g/100 g FA) & T2 (g/100 g FA) \\
\hline C12:0 & Lauric acid & $0.00 \pm 0.00^{\mathrm{a}}$ & $2.06 \pm 0.04^{\mathrm{ab}}$ & $4.43 \pm 0.04^{\mathrm{b}}$ \\
\hline C14:0 & Myristic acid & $1.04 \pm 0.02^{\mathrm{a}}$ & $3.38 \pm 0.03^{\mathrm{ab}}$ & $4.55 \pm 0.02^{\mathrm{b}}$ \\
\hline C15:0 & Pentadecanoic acid & $0.42 \pm 0.01^{\mathrm{a}}$ & $0.45 \pm 0.03^{\mathrm{ab}}$ & $0.62 \pm 0.00^{\mathrm{b}}$ \\
\hline C16:0 & Palmitic acid & $18.36 \pm 0.49^{\mathrm{a}}$ & $23.62 \pm 0.26^{\mathrm{b}}$ & $20.64 \pm 0.11^{\mathrm{b}}$ \\
\hline C16:1 & Palmitoleic ac. & $0.73 \pm 0.06^{\mathrm{a}}$ & $1.46 \pm 0.01^{\mathrm{ab}}$ & $1.57 \pm 0.02^{\mathrm{b}}$ \\
\hline C18:0 & Stearic acid & $4.90 \pm 0.06^{\mathrm{a}}$ & $4.90 \pm 0.06^{\mathrm{ab}}$ & $3.94 \pm 0.02^{\mathrm{b}}$ \\
\hline $\mathrm{C} 18: 1 \mathrm{n} 9$ & Oleic acid & $22.95 \pm 0.36^{\mathrm{a}}$ & $22.46 \pm 0.18^{\mathrm{ab}}$ & $20.98 \pm 0.08^{\mathrm{b}}$ \\
\hline $\mathrm{C} 18: 1 \mathrm{n} 7$ & Vaccenic acid & $1.04 \pm 0.02^{\mathrm{a}}$ & $1.15 \pm 0.02^{\mathrm{a}}$ & $0.0 \pm 0.00^{\mathrm{a}}$ \\
\hline $\mathrm{C} 18: 2 \mathrm{n} 6$ & Linoleic acid & $43.61 \pm 0.66^{\mathrm{a}}$ & $34.65 \pm 0.39^{\mathrm{ab}}$ & $37.13 \pm 0.14^{\mathrm{b}}$ \\
\hline $\mathrm{C} 18: 3 \mathrm{n} 3$ & Linolenic acid & $6.89 \pm 0.26^{\mathrm{a}}$ & $5.99 \pm 0.13^{\mathrm{ab}}$ & $5.78 \pm 0.06^{\mathrm{b}}$ \\
\hline $\mathrm{C} 20: 4 \mathrm{n} 6$ & Arachidonic acid & $0.00 \pm 0.00^{\mathrm{a}}$ & $0.03 \pm 0.00^{\mathrm{a}}$ & $0.37 \pm 0.03^{\mathrm{a}}$ \\
\hline
\end{tabular}


Table 6. Cont.

\begin{tabular}{cccc}
\hline Fatty Acids & T0 (g/100 g FA) & T1 (g/100 g FA) & T2 (g/100 g FA) \\
\hline Omega 3 & $0.33 \pm 0.01^{\mathrm{a}}$ & $0.44 \pm 0.01^{\mathrm{ab}}$ & $0.47 \pm 0.00^{\mathrm{b}}$ \\
\hline Omega 6 & $2.09 \pm 0.05^{\mathrm{a}}$ & $2.51 \pm 0.10^{\mathrm{ab}}$ & $3.05 \pm 0.02^{\mathrm{b}}$ \\
\hline n6/n3 & $6.35 \pm 0.14^{\mathrm{a}}$ & $5.71 \pm 0.03^{\mathrm{b}}$ & $6.48 \pm 0.06^{\mathrm{a}}$ \\
\hline Polyunsaturated Fatty Acid (P) & $2.42 \pm 0.06^{\mathrm{a}}$ & $2.95 \pm 0.11^{\mathrm{ab}}$ & $3.52 \pm 0.03^{\mathrm{b}}$ \\
\hline P/S & $2.04 \pm 0.08^{\mathrm{a}}$ & $1.21 \pm 0.03^{\mathrm{b}}$ & $1.27 \pm 0.01^{\mathrm{b}}$
\end{tabular}

Note: Values are means of quadruplicate \pm standard error. Different letters $(a, b)$ in the same row are significantly different at $(p<0.05)$ according to Kruskal-Wallis test.

\subsection{Sustainability Aspects}

The amount of feed and its composition contribute highly to the environmental impacts of both insects and guinea pigs. C. porcellus is characterized with a relatively low feed conversion rate: 4.7 for feed itself and 18.7 if maize forage is included. Insects can also have a relatively high impact (Table 7). At the same time, the selection of insects grown on sideor waste-streams for C. porcellus can reduce their environmental impact.

Table 7. Environmental impacts of feed and C. porcellus meat grown on different diets (functional unit $1 \mathrm{~kg}$ dry weight).

\begin{tabular}{ccccc}
\hline & \multicolumn{4}{c}{ Impact Category } \\
\hline Products (feeds and meat) & $\mathrm{m}^{2}$ org.a & GWP & NER & WU \\
\hline HM1 & 1.89 & 3.00 & 84.18 & 2.77 \\
\hline HM2 & 0.0002 & 1.00 & 7.20 & 190.00 \\
\hline T0 & 1.20 & 0.48 & 3.55 & 256.00 \\
\hline Soymeal & 1.39 & 0.70 & 4.19 & 254.00 \\
\hline GP & 11.04 & 10.43 & 30.97 & 1942.07 \\
\hline GPonHM1 & 13.81 & 24.39 & 617.98 & 847.69 \\
\hline GPonHM2 & 6.85 & 15.32 & 54.83 & 2578.33
\end{tabular}

Note: HM1-H. illucens meal with insects grown on high quality commercial diet [41]; HM2—H. illucens meal with insects grown on side-streams and food waste [42-45]; T0 - impact of diet composed with maize forage and $100 \%$ protein supply from soybean meal; GP-C. porcellus grown on T0 diet; GPonHM1 - C. porcellus grown on a diet with inclusion of HM1; GPonHM2-C. porcellus grown on a diet with inclusion of HM2; LU-land use; GWP—global warming potential; NER—non-renewable energy use; WU—water use; * [46-48].

An environmental impact assessment indicated that the small-scale production of guinea pigs could have a relatively high impact on the environment if they are grown on a high-quality commercial feed, and even higher if the same feed is transformed by the $H$. illucens and then fed to C. porcellus. At the same time, the production of C. porcellus on $H$. illucens grown on agri-food residuals had an environmental impact similar to the impact of guinea pigs grown on a commercial diet. Further research is needed to determine the environmental feasibility of joint $C$. porcellus on $H$. illucens production under a circular economy model.

\section{Discussion}

\subsection{WHC, $\mathrm{pH}$ and Colour}

The average $\mathrm{pH}$ value (5.88) we recorded in guinea pig meat is close to values reported in other studies [29,49]. Apparently, $\mathrm{pH}$ is more influenced by rigor mortis and other factors related to stress [29] than diet. Since pH strongly influences WHC [49], having similar pH 
values in meat from treatments $\mathrm{T} 0, \mathrm{~T} 1$, and $\mathrm{T} 2$ resulted in no differences in WHC. The water-holding capacity (WHC) is one of the most important factors affecting the economic value and quality of meat. Additionally, WHC is closely related to the color, texture, and firmness of raw meat [50]. Color remains one of the most important meat quality attributes for consumers. Diet has been suggested as one of the most important pre-harvest factors influencing meat color [51]. Nevertheless, H. illucens meal did not significantly affect the meat color, with this being in accordance with the results of a previous study that reported no difference in color between samples of broiler breast meat fed with different proportions of black soldier fly meal [52]. Our results show that WHC, color, and $\mathrm{pH}$ are apparently not significantly affected by the replacement of soy by BSF in the diet. Therefore, the total replacement of soybean with BSF is possible since the substitution did not affect the main meat quality parameters.

\subsection{Proximate Composition}

Meat protein content is similar in the three different treatments (T0, T1, and T2), mostly due to the similarity between the amino acid profiles of the diets. A focus on protein content is mandatory considering that protein sources are expensive and scarce for people in Andean regions. Similarly, proteins are the most expensive nutrients in guinea pig nutrition, hence the total replacement of soybean meal with black soldier fly larvae meal could be a good alternative in guinea pigs rearing, especially considering that BSF meal is considered among the most sustainable protein sources [53,54]. In addition, rearing $H$. illucens on agri-food wastes to obtain protein sources for animal nutrition could play a significant role in the circularity of important nutrients in local food systems.

The values of protein $(18 \%)$, fat $(7 \%)$, moisture $(73 \%)$, and ash $(1 \%)$ in the meat of guinea pigs found in this study are similar to those reported by others $[55,56]$, suggesting that the meat proximate composition is not strongly influenced by variations in diet as long as all nutritional requirements are satisfied. Compared to values reported by Lozano et al. [57], guinea pig meat showed slightly lower protein content than hen (25\%), chicken $(23 \%)$, beef $(21 \%)$, turkey $(20 \%)$, pork $(22 \%)$, and rabbit $(21 \%)$ meat. Regarding fat, the guinea pig meat $(7 \%)$ showed similar content to lamb $(7 \%)$ and rabbit $(7 \%)$ meat but much higher than hen $(1 \%)$, chicken $(1 \%)$, beef $(2 \%)$, turkey $(3 \%)$, and pork $(5 \%)$ meat. Still, guinea pig remains the principal high-quality animal protein (see the amino acid profile results) source for people of Andean regions, considering that these animals also have high proliferation and rapid growth and are fed mainly with forage, not competing directly with humans for food resources such as corn and wheat [49]. Moreover, guinea pigs are perfectly suited for smallholder rural farmers since they can be used as food and marketable products indistinctly [58], and have a good feed conversion ratio, which is a special concern in livestock systems $[59,60]$.

In this study, the commercial formula was only changed regarding the replacement of soybean meal, hence the advantages and limitations of using BSF meal need to be further investigated to optimize diets considering local conditions on forage availability and seasonality, and specifically how the BSF meal nutritional profile changes with rearing conditions and the effect on guinea pig meat quality.

\subsection{Amino Acid Profile}

The amino acid profiles of the guinea pig meat fed the three different diets were similar, regardless of whether the protein of the feed was soybean meal or different levels of black soldier fly larvae meal. These results agree with those of [26] for cooked chicken breast meat fed different levels of soldier fly larvae meal, where they found that there was no variation in the amino acid levels. Similarly, [61] reported no difference in amino acid profiles in juvenile grass carps fed different diets (soybean meal and 10, 25, 50, 75, and 100\% substitution of soybean with black soldier fly larvae meal). The amino acid profiles of the diets (T0, T1, and T2), shown previously (Table 1), were very similar, and considering that methionine and lysine were added to diets, it is probable that guinea pigs fulfilled all the 
essential amino acids needed, reflecting a similar amino acid profile in meat. However, the levels of Arginine, Methionine and Tryptophan were higher in concentrates with the total replacement of soybean meal with BSF meal. Considering that these are essential amino acids for guinea pigs [62], it can be inferred that BSF performs better than soybean as a feed ingredient. Hence, further investigations assessing the optimization of feed ingredients (nutritionally and economically) are necessary to support rural smallholder famers and improve the sustainability of guinea pig meat.

An increase in aspartic acid, glutamic acid, alanine, serine, tyrosine, and threonine in quail breast meat after introducing 15\% defatted black soldier fly larvae meal in the diet was found by [63]. The differences found may be due to the different levels of inclusion of the soldier fly larvae meal in the food, as well as the differences between the animal species studied. Lower amino acid content in quail breast meat fed with a diet of $10 \%$ black soldier fly larvae meal compared to those fed with no black soldier fly larvae was found by [52]. It was stated that the difference was due to the use of whole black soldier fly larvae meal instead of defatted one. However, in these studies, no nutritional requirements of quail were mentioned.

Compared to other meats (Table 5), the content of essential amino acids found in this study for guinea pig meat have mostly similar values, except for lysine, histidine, and methionine, which were lower than those in beef, pork, chicken, and rabbit $[38,39]$. No amino acid profile studies were found in guinea pig meat to be able to compare the results obtained. Nonetheless, guinea pig meat fulfills the recommended concentration for essential amino acids (FAO/WHO, 2013) and thus represents a good animal protein source, especially for people in Andean regions.

\subsection{Fatty Acid Profile}

The concentration of n-3 PUFA (polyunsaturated fatty acids) in animal tissues depends mainly on the fatty acid composition of the diet. A dietary imbalance of the n-6:n-3 PUFA ratio can affect human health, especially with a high n-6:n-3 PUFA ratio in our modern diets; thus, it is recommended that the n-6:n-3 PUFA ratio should be nearly 3:1 to 1:1 [64]. Our study showed that the diet had a significant impact on the omega 6 and omega 3 content of the meat, as well as the content of saturated and polyunsaturated fatty acids. Nevertheless, the n-6:n-3 ratio showed no differences between the control and total replacement with BSF meal. This occurred mainly due to the simultaneous increase in linolenic acid (n-3) (42\%) and linoleic acid (n-6) (43\%) in guinea pigs fed with H. illucens.

There are several studies on guinea pigs that demonstrate that the fatty acid profile of the guinea pig changes with the feed given [65]. We found a slight increment of the n-6:n-3 ratio in T2, therefore it is necessary to further explore the influence of BSF larvae meal, considering that the diet formula includes soy oil (rich in linoleic acid-C18:2 n6) in all three experimental diets. Nevertheless, guinea pig n-6:n-3 ratios (5.7-6.5) are higher than [66] or similar to [67] reported ratios of beef and higher than lamb [68], chicken [69], alpaca, and llama [70], while only showing lower ratios than pork [71] and quail [52].

The n-6:n-3 ratio was reduced in quail breast meat thanks to black soldier fly larvae meal in their diet as reported by [52]; although, larvae were reared using fish oil in their diets (rich in n-3 fatty acids). Although no significant differences in the n-6:n-3 ratio were found between T0, T1, and T2, guinea pigs fed with black soldier fly larvae meal showed a total increment of $11 \%$ in this ratio compared to those fed with soybean meal, thus further research is needed to assess if this ratio can be improved by defatting the insect meal or controlling the diets of insects, aiming to obtain a better fatty acid profile.

The recommended ratio of polyunsaturated fatty acids (PUFA) to saturated fatty acids $(\mathrm{P} / \mathrm{S})$ should be above 0.4 . Since some meats naturally have a $\mathrm{P} / \mathrm{S}$ ratio of around 0.1 , meat has been implicated in causing the imbalanced fatty acid intake of today's consumers [72]. In this research, $\mathrm{P} / \mathrm{S}$ ratios showed no significant differences between diets containing BSF meal but did show a significant difference from the control, mainly due to a significant increment of $57 \%$ in saturated fatty acids (S) against a much lesser increment (32\%) in 
polyunsaturated fatty acids (P). Moreover, $\mathrm{P} / \mathrm{S}$ ranged from 1.17 to 2.2 , which is higher than those reported by [73], which ranged from 1.22 to 1.48 , indicating a good $\mathrm{P} / \mathrm{S}$ ratio. Nevertheless, it is important to remark that the $\mathrm{P} / \mathrm{S}$ ratio decreased with the substitutions of BSF in diets. Therefore, further research is needed, focusing on the variations in saturated fatty acids in BSF meal, which could affect the meat $\mathrm{P} / \mathrm{S}$ ratio.

On the other hand, the desirable fats, referred to as the sum of the monounsaturated fatty acids, polyunsaturated fatty acids, and C18 fatty acids [74], showed an increment in those diets with black soldier fly larvae meal (T0: $3.9 \pm 0.2$, T1: $5.2 \pm 0.3, \mathrm{~T} 2: 5.9 \pm 0.1$ ) representing a $34 \%$ enhancement compared to guinea pigs fed with soybean meal; thus, the desirable fatty acids in the meat of the guinea pigs fed with black soldier fly larvae meal could be considered better than those with a soybean meal-based diet. Still, undesirable fats (saturated) also showed an increment, as already mentioned above.

Previous studies, especially in poultry, highlight the increase in saturated fatty acid in meat as a negative aspect when increasing the H. illucens content in the diet [75-77]. Moreover, some focus on improving the polyunsaturated fatty acids in insect meals using rearing substrates richer in omega 3 to overcome that problem [78-80]. It has also been suggested to use defatted black soldier fly larvae meal in feeding broiler chickens to avoid the high contribution of saturated fatty acids [27]. Hence, to improve the P/S and n-6/n-3 ratios in guinea pig meat, it could be convenient to use defatted black soldier larvae meal and incorporate other types of fat sources (i.e., vegetable oil) richer in n-3 fatty acids to the guinea pig diet or change the rearing substrate for H. illucens to obtain meals with better fatty acid profiles. However, both alternatives demand more complex procedures and would potentially raise the meal cost. Therefore, it is necessary to further investigate the topic. Perhaps it would be more practical for humans to incorporate n-3 fatty acids in their diet from other sources instead of modulating n-3 fatty acids in meat.

\section{Conclusions}

The results of our study showed that black soldier fly larvae meal can replace soybean meal as a feed ingredient for guinea pigs since the nutritional profile and quality parameters of meat were largely maintained. Nevertheless, special attention should be paid to the increment in saturated fats, derived from the inclusion of BSF in the guinea pig diet.

The use of BSF meal as a feed ingredient for guinea pigs could be beneficial in areas of low availability of commercially supplied protein sources (soy or fishmeal). However, further studies dealing with the economic and social feasibility of such solutions especially under the conditions of a circular economy and the potential increase in production volumes are needed.

Author Contributions: Conceptualization, B.S.-R. and S.S; methodology, B.S.-R., E.H. and A.N.; validation, J.-I.P., V.H., S.S. and V.A.; formal analysis, K.C.; writing-original draft preparation: B.S.-R., E.H. and V.A.; writing—review and editing: B.S.-R., J.-I.P. and S.S.; visualization, E.H. and A.N.; supervision, E.H., V.H. and S.S.; funding acquisition, E.H. and S.S. All authors have read and agreed to the published version of the manuscript.

Funding: The research is partially supported by the German Federal Ministry of Education and Research (BMBF), grant number 01DN17017 in association with the Peruvian National Fund for Scientific and Technological Development and Technological Innovation (grant number FONDECYT 016-2016) through thee Era-Net LAC project EntoWaste (ELAC2015/T03-0580), and partially by the European Union's Horizon 2020 research and innovation programme under the grant agreement no. 861976 project SUSINCHAIN.

Institutional Review Board Statement: Not applicable.

Informed Consent Statement: Not applicable.

Data Availability Statement: Not applicable. 
Conflicts of Interest: The authors declare no conflict of interest. The funders had no role in the design of the study; in the collection, analyses, or interpretation of data; in the writing of the manuscript, or in the decision to publish the results.

\section{References}

1. Keller, M.; Reidy, B.; Scheurer, A.; Eggerschwiler, L.; Morel, I.; Giller, K. Soybean Meal Can Be Replaced by Faba Beans, Pumpkin Seed Cake, Spirulina or Be Completely Omitted in a Forage-Based Diet for Fattening Bulls to Achieve Comparable Performance, Carcass and Meat Quality. Animals 2021, 11, 1588. [CrossRef] [PubMed]

2. Mbhele, F.G.T.; Mnisi, C.M.; Mlambo, V. A Nutritional Evaluation of Insect Meal as a Sustainable Protein Source for Jumbo Quails: Physiological and Meat Quality Responses. Sustainability 2019, 11, 6592. [CrossRef]

3. Patsios, S.I.; Dedousi, A.; Sossidou, E.N.; Zdragas, A. Sustainable Animal Feed Protein through the Cultivation of YARROWIA Lipolytica on Agro-Industrial Wastes and by-Products. Sustainability 2020, 12, 1398. [CrossRef]

4. Hawkey, K.J.; Lopez-Viso, C.; Brameld, J.M.; Parr, T.; Salter, A.M. Insects: A Potential Source of Protein and Other Nutrients for Feed and Food. Annu. Rev. Anim. Biosci. 2021, 9, 333-354. [CrossRef]

5. Kim, H.W.; Setyabrata, D.; Lee, Y.J.; Jones, O.G.; Kim, Y.H.B. Pre-Treated Mealworm Larvae and Silkworm Pupae as a Novel Protein Ingredient in Emulsion Sausages. Innov. Food Sci. Emerg. Technol. 2016, 38, 116-123. [CrossRef]

6. Smetana, S.; Leonhardt, L.; Kauppi, S.-M.; Pajic, A.; Heinz, V. Insect Margarine: Processing, Sustainability and Design. J. Clean. Prod. 2020, 264, 121670. [CrossRef]

7. Smetana, S.; Mathys, A.; Knoch, A.; Heinz, V. Meat Alternatives: Life Cycle Assessment of Most Known Meat Substitutes. Int. J. Life Cycle Assess. 2015, 20, 1254-1267. [CrossRef]

8. Smetana, S.; Palanisamy, M.; Mathys, A.; Heinz, V. Sustainability of Insect Use for Feed and Food: Life Cycle Assessment Perspective. J. Clean. Prod. 2016, 137, 741-751. [CrossRef]

9. van Huis, A. Prospects of Insects as Food and Feed. Org. Agric. 2021, 11, 301-308. [CrossRef]

10. Broeckx, L.; Frooninckx, L.; Slegers, L.; Berrens, S.; Noyens, I.; Goossens, S.; Verheyen, G.; Wuyts, A.; van Miert, S. Growth of Black Soldier Fly Larvae Reared on Organic Side-Streams. Sustainability 2021, 13, 2953. [CrossRef]

11. Madibana, M.J.; Mwanza, M.; Lewis, B.R.; Fouché, C.H.; Toefy, R.; Mlambo, V. Black Soldier Fly Larvae Meal as a Fishmeal Substitute in Juvenile Dusky Kob Diets: Effect on Feed Utilization, Growth Performance, and Blood Parameters. Sustainability 2020, 12, 9460. [CrossRef]

12. Oteri, M.; di Rosa, A.R.; lo Presti, V.; Giarratana, F.; Toscano, G.; Chiofalo, B. Black Soldier Fly Larvae Meal as Alternative to Fish Meal for Aquaculture Feed. Sustainability 2021, 13, 5447. [CrossRef]

13. Sumbule, E.K.; Ambula, M.K.; Osuga, I.M.; Changeh, J.G.; Mwangi, D.M.; Subramanian, S.; Salifu, D.; Alaru, P.A.O.; Githinji, M.; van Loon, J.J.A.; et al. Cost-Effectiveness of Black Soldier Fly Larvae Meal as Substitute of Fishmeal in Diets for Layer Chicks and Growers. Sustainability 2021, 13, 6074. [CrossRef]

14. Veldkamp, T.; Bosch, G. Insects: A Protein-Rich Feed Ingredient in Pig and Poultry Diets. Anim. Front. $2015,5,45-50$.

15. Allegretti, G.; Talamini, E.; Schmidt, V.; Bogorni, P.C.; Ortega, E. Insect as Feed: An Emergy Assessment of Insect Meal as a Sustainable Protein Source for the Brazilian Poultry Industry. J. Clean. Prod. 2018, 171, 403-412. [CrossRef]

16. Magalhães, R.; Sánchez-López, A.; Leal, R.S.; Martínez-Llorens, S.; Oliva-Teles, A.; Peres, H. Black Soldier Fly (Hermetia Illucens) Pre-Pupae Meal as a Fish Meal Replacement in Diets for European Seabass (Dicentrarchus Labrax). Aquaculture 2017, 476, 79-85. [CrossRef]

17. Nyakeri, E.M.; Ogola, H.J.; Ayieko, M.A.; Amimo, F.A. An Open System for Farming Black Soldier Fly Larvae as a Source of Proteins for Smallscale Poultry and Fish Production. J. Insects Food Feed 2017, 3, 51-56. [CrossRef]

18. Renna, M.; Schiavone, A.; Gai, F.; Dabbou, S.; Lussiana, C.; Malfatto, V.; Prearo, M.; Capucchio, M.T.; Biasato, I.; Biasibetti, E.; et al. Evaluation of the Suitability of a Partially Defatted Black Soldier Fly (Hermetia Illucens L.) Larvae Meal as Ingredient for Rainbow Trout (Oncorhynchus Mykiss Walbaum) Diets. J. Anim. Sci. Biotechnol. 2017, 8, 57. [CrossRef]

19. Liu, X.; Chen, X.; Wang, H.; Yang, Q.; ur Rehman, K.; Li, W.; Cai, M.; Li, Q.; Mazza, L.; Zhang, J.; et al. Dynamic Changes of Nutrient Composition throughout the Entire Life Cycle of Black Soldier Fly. PLoS ONE 2017, 12, e0182601. [CrossRef]

20. Loponte, R.; Nizza, S.; Bovera, F.; de Riu, N.; Fliegerova, K.; Lombardi, P.; Vassalotti, G.; Mastellone, V.; Nizza, A.; Moniello, G. Growth Performance, Blood Profiles and Carcass Traits of Barbary Partridge (Alectoris Barbara) Fed Two Different Insect Larvae Meals (Tenebrio Molitor and Hermetia Illucens). Res. Vet. Sci. 2017, 115, 183-188. [CrossRef]

21. Elhag, O.; Zhou, D.; Song, Q.; Soomro, A.A.; Cai, M.; Zheng, L.; Yu, Z.; Zhang, J. Screening, Expression, Purification and Functional Characterization of Novel Antimicrobial Peptide Genes from Hermetia Illucens (L.). PLoS ONE 2017, 12, e0169582. [CrossRef] [PubMed]

22. Xia, J.; Ge, C.; Yao, H. Antimicrobial Peptides from Black Soldier Fly (Hermetia Illucens) as Potential Antimicrobial Factors Representing an Alternative to Antibiotics in Livestock Farming. Animals 2021, 11, 1937. [CrossRef] [PubMed]

23. Chia, S.Y.; Tanga, C.M.; Osuga, I.M.; Alaru, A.O.; Mwangi, D.M.; Githinji, M.; Dubois, T.; Ekesi, S.; van Loon, J.J.A.; Dicke, M. Black Soldier Fly Larval Meal in Feed Enhances Growth Performance, Carcass Yield and Meat Quality of Finishing Pigs. J. Insects Food Feed 2021, 7, 433-447. [CrossRef]

24. Veldkamp, T.; Vernooij, A.G. Use of Insect Products in Pig Diets. J. Insects Food Feed 2021, 7, 781-793. [CrossRef] 
25. Yu, M.; Li, Z.; Chen, W.; Rong, T.; Wang, G.; Li, J.; Ma, X. Use of Hermetia Illucens Larvae as a Dietary Protein Source: Effects on Growth Performance, Carcass Traits, and Meat Quality in Finishing Pigs. Meat Sci. 2019, 158, 107837. [CrossRef]

26. Pieterse, E.; Erasmus, S.W.; Uushona, T.; Hoffman, L.C. Black Soldier Fly (Hermetia Illucens) Pre-Pupae Meal as a Dietary Protein Source for Broiler Production Ensures a Tasty Chicken with Standard Meat Quality for Every Pot. J. Sci. Food Agric. 2019, 99, 893-903. [CrossRef]

27. Schiavone, A.; Dabbou, S.; Petracci, M.; Zampiga, M.; Sirri, F.; Biasato, I.; Gai, F.; Gasco, L. Black Soldier Fly Defatted Meal as a Dietary Protein Source for Broiler Chickens: Effects on Carcass Traits, Breast Meat Quality and Safety. Animal 2019, 13, $2397-2405$. [CrossRef]

28. Dalle Zotte, A.; Cullere, M. Carcass Traits and Meat Quality of Rabbit, Hare, Guinea Pig and Capybara. In More than Beef, Pork and Chicken-The Production, Processing, and Quality Traits of Other Sources of Meat for Human Diet; Springer International Publishing: Cham, Switzerland, 2019; pp. 167-210.

29. Sánchez-Macías, D.; Cevallos-Velastegui, L.; Nuñez-Valle, D.; Morales-delaNuez, A. First Report of Postmortem PH Evolution and Rigor Mortis in Guinea Pigs. Livest. Sci. 2019, 229, 22-27. [CrossRef]

30. National Research Council (US). Nutrient Requirements of Laboratory Animals; National Academies Press: Washington, DC, USA, 1995.

31. Chauca, L. Producción de Cuyes (Cavia Porcellus); Food \& Agriculture Organization: Rome, Italy, 1997; Volume 138, ISBN 9253040335.

32. Honikel, K.O. Reference Methods for the Assessment of Physical Characteristics of Meat. Meat Sci. 1998, 49, 447-457. [CrossRef]

33. AOAC. Official Methods of Analysis of AOAC International; AOAC International: Rockville, MD, USA, 2016.

34. Heinrikson, R.L.; Meredith, S.C. Amino Acid Analysis by Reverse-Phase High-Performance Liquid Chromatography: Precolumn Derivatization with Phenylisothiocyanate. Anal. Biochem. 1984, 136, 65-74. [CrossRef]

35. Benjamini, Y.; Hochberg, Y. Controlling the False Discovery Rate: A Practical and Powerful Approach to Multiple Testing. J. R. Stat. Soc. Ser. B (Methodol.) 1995, 57, 289-300. [CrossRef]

36. Jolliet, O.; Margni, M.; Charles, R.; Humbert, S.; Payet, J.; Rebitzer, G.; Rosenbaum, R. IMPACT 2002+: A New Life Cycle Impact Assessment Methodology. Int. J. Life Cycle Assess. 2003, 8, 324. [CrossRef]

37. Humbert, S.; Schryver, A.; Bengoa, X.; Margni, M.; Jolliet, O. IMPACT 2002+: User Guide; Quantis: Lausanne, Switzerland, 2012.

38. Tessari, P.; Lante, A.; Mosca, G. Essential Amino Acids: Master Regulators of Nutrition and Environmental Footprint? Sci. Rep. 2016, 6, 26074. [CrossRef] [PubMed]

39. Li, S.; He, Z.; Hu, Y.; Li, H. Shotgun Proteomic Analysis of Protein Profile Changes in Female Rabbit Meat: The Effect of Breed and Age. Ital. J. Anim. Sci. 2019, 18, 1335-1344. [CrossRef]

40. Food and Agriculture Organization of the United Nations. Dietary Protein Quality Evaluation in Human Nutrition: Report of an FAO Expert Consultation, 31 March-2 April, 2011, Auckland, New Zealand; Food and Agriculture Organization of the United Nations: Rome, Italy, 2013; ISBN 9789251074176.

41. Smetana, S.; Schmitt, E.; Mathys, A. Sustainable Use of Hermetia Illucens Insect Biomass for Feed and Food: Attributional and Consequential Life Cycle Assessment. Resour. Conserv. Recycl. 2019, 144, 285-296. [CrossRef]

42. Salomone, R.; Saija, G.; Mondello, G.; Giannetto, A.; Fasulo, S.; Savastano, D. Environmental Impact of Food Waste Bioconversion by Insects: Application of Life Cycle Assessment to Process Using Hermetia Illucens. J. Clean. Prod. 2017, 140, 890-905. [CrossRef]

43. Ites, S.; Smetana, S.; Toepfl, S.; Heinz, V. Modularity of Insect Production and Processing as a Path to Efficient and Sustainable Food Waste Treatment. J. Clean. Prod. 2020, 248, 119248. [CrossRef]

44. Smetana, S.; Spykman, R.; Heinz, V. Environmental Aspects of Insect Mass Production. J. Insects Food Feed 2021, 7, 1-20. [CrossRef]

45. Spykman, R.; Hossaini, S.M.; Peguero, D.A.; Green, A.; Heinz, V.; Smetana, S. A Modular Environmental and Economic Assessment Applied to the Production of Hermetia Illucens Larvae as a Protein Source for Food and Feed. Int. J. Life Cycle Assess. 2021, 26, 1959-1976. [CrossRef]

46. Saerens, W.; Smetana, S.; van Campenhout, L.; Lammers, V.; Heinz, V. Life Cycle Assessment of Burger Patties Produced with Extruded Meat Substitutes. J. Clean. Prod. 2021, 306, 127177. [CrossRef]

47. Dalgaard, R.; Schmidt, J.; Halberg, N.; Christensen, P.; Thrane, M.; Pengue, W.A. LCA of Soybean Meal. Int. J. Life Cycle Assess. 2008, 13, 240-254. [CrossRef]

48. Durlinger, B.; Koukouna, E.; Broekema, R.; van Paassen, M.; Scholten, J. Agri-Footprint 3.0; Agri-Footprint: Gouda, The Netherlands, 2017.

49. de Figueiredo, L.B.F.; de Souza Rodrigues, R.T.; Leite, M.F.S.; Gois, G.C.; da Silva Araújo, D.H.; de Alencar, M.G.; Oliveira, T.P.R.; Figueirêdo Neto, A.; Silva Junior, R.G.C.; Queiroz, M.A.Á. Effect of Sex on Carcass Yield and Meat Quality of Guinea Pig. J. Food Sci. Technol. 2020, 57, 3024-3030. [CrossRef]

50. Barbera, S. WHCtrend, an up-to-Date Method to Measure Water Holding Capacity in Meat. Meat Sci. 2019, 152, 134-140. [CrossRef] [PubMed]

51. Tomasevic, I.; Djekic, I.; Font-i-Furnols, M.; Terjung, N.; Lorenzo, J.M. Recent Advances in Meat Color Research. Curr. Opin. Food Sci. 2021, 41, 81-87. [CrossRef]

52. Cullere, M.; Schiavone, A.; Dabbou, S.; Gasco, L.; Dalle Zotte, A. Meat Quality and Sensory Traits of Finisher Broiler Chickens Fed with Black Soldier Fly (Hermetia Illucens L.) Larvae Fat as Alternative Fat Source. Animals 2019, 9, 140. [CrossRef] [PubMed]

53. Wang, Y.-S.; Shelomi, M. Review of Black Soldier Fly (Hermetia Illucens) as Animal Feed and Human Food. Foods 2017, 6, 91. [CrossRef] [PubMed] 
54. Walter, A.; Klammsteiner, T.; Gassner, M.; Heussler, C.D.; Kapelari, S.; Schermer, M.; Insam, H. Black Soldier Fly School Workshops as Means to Promote Circular Economy and Environmental Awareness. Sustainability 2020, 12, 9574. [CrossRef]

55. Flores-Mancheno, C.I.; Duarte, C.; Salgado-Tello, I.P. Caracterización de La Carne de Cuy (Cavia Porcellus) Para Utilizarla En La Elaboración de Un Embutido Fermentado. Cienc. Y Agric. 2017, 14, 39-45. [CrossRef]

56. Sánchez-Macías, D.; Barba-Maggi, L.; Morales-delaNuez, A.; Palmay-Paredes, J. Guinea Pig for Meat Production: A Systematic Review of Factors Affecting the Production, Carcass and Meat Quality. Meat Sci. 2018, 143, 165-176. [CrossRef]

57. Lozano, M.; Rodríguez-Ulibarri, P.; Echeverría, J.C.; Beruete, M.; Sorolla, M.; Beriain, M.J. Mid-Infrared Spectroscopy (MIR) for Simultaneous Determination of Fat and Protein Content in Meat of Several Animal Species. Food Anal. Methods 2017, 10, 3462-3470. [CrossRef]

58. Lammers, P.J.; Carlson, S.L.; Zdorkowski, G.A.; Honeyman, M.S. Reducing Food Insecurity in Developing Countries through Meat Production: The Potential of the Guinea Pig ( Cavia Porcellus). Renew. Agric. Food Syst. 2009, 24, 155-162. [CrossRef]

59. Wilkinson, J.M. Re-Defining Efficiency of Feed Use by Livestock. Animal 2011, 5, 1014-1022. [CrossRef] [PubMed]

60. Mottet, A.; de Haan, C.; Falcucci, A.; Tempio, G.; Opio, C.; Gerber, P. Livestock: On Our Plates or Eating at Our Table? A New Analysis of the Feed/Food Debate. Glob. Food Secur. 2017, 14, 1-8. [CrossRef]

61. Lu, R.; Chen, Y.; Yu, W.; Lin, M.; Yang, G.; Qin, C.; Meng, X.; Zhang, Y.; Ji, H.; Nie, G. Defatted Black Soldier Fly (Hermetia Illucens) Larvae Meal Can Replace Soybean Meal in Juvenile Grass Carp (Ctenopharyngodon Idellus) Diets. Aquac. Rep. 2020, 18, 100520. [CrossRef]

62. Reid, M.E.; Mickelsen, O. Nutritional Studies with the Guinea Pig: VIII. Effect of Different Proteins, with and without Amino Acid Supplements, on Growth. J. Nutr. 1963, 80, 25-32.

63. Cullere, M.; Tasoniero, G.; Giaccone, V.; Acuti, G.; Marangon, A.; Dalle Zotte, A. Black Soldier Fly as Dietary Protein Source for Broiler Quails: Meat Proximate Composition, Fatty Acid and Amino Acid Profile, Oxidative Status and Sensory Traits. Animal 2018, 12, 640-647. [CrossRef]

64. Ibrahim, D.; El-Sayed, R.; Khater, S.I.; Said, E.N.; El-Mandrawy, S.A.M. Changing Dietary N-6:N-3 Ratio Using Different Oil Sources Affects Performance, Behavior, Cytokines MRNA Expression and Meat Fatty Acid Profile of Broiler Chickens. Anim. Nutr. 2018, 4, 44-51. [CrossRef]

65. Jorge Guevara, V.; Sergio Rojas, M.; Fernando Carcelén, C.; Luis Seminario, S. Enrichment of Guinea Pig (Cavia Porcellus) Meat with Omega-3 Fatty Acids by Diets with Fish Oil and Sacha Inchi (Plukenetia Volubilis) Seeds. Rev. De Investig. Vet. Del Peru 2016, 27, 45-50. [CrossRef]

66. Kamihiro, S.; Stergiadis, S.; Leifert, C.; Eyre, M.D.; Butler, G. Meat Quality and Health Implications of Organic and Conventional Beef Production. Meat Sci. 2015, 100, 306-318. [CrossRef]

67. Cheng, G.; Fu, C.; Wang, H.; Adoligbe, C.; Wei, S.; Li, S.; Jiang, B.; Wang, H.; Zan, L. Production of Transgenic Beef Cattle Rich in N-3 PUFAs by Somatic Cell Nuclear Transfer. Biotechnol. Lett. 2015, 37, 1565-1571. [CrossRef]

68. Thomas, E.M.; Roden, J.A.; Haresign, W.; Richardson, R.I.; Lambe, N.R.; Clelland, N.; Gardner, G.E.; Scollan, N.D. Meat Eating and Nutritional Quality of Lambs Sired by High and Low Muscle Density Rams. Animal 2021, 15, 100136. [CrossRef] [PubMed]

69. Abbasi, F.; Samadi, F.; Jafari, S.M.; Ramezanpour, S.; Shams-Shargh, M. Production of Omega-3 Fatty Acid-Enriched Broiler Chicken Meat by the Application of Nanoencapsultsed Flaxseed Oil Prepared via Ultrasonication. J. Funct. Foods 2019, 57, 373-381. [CrossRef]

70. Popova, T.; Tejeda, L.; Peñarrieta, J.M.; Smith, M.A.; Bush, R.D.; Hopkins, D.L. Meat of South American Camelids—Sensory Quality and Nutritional Composition. Meat Sci. 2021, 171, 108285. [CrossRef] [PubMed]

71. Huang, C.; Chiba, L.I.; Bergen, W.G. Bioavailability and Metabolism of Omega-3 Polyunsaturated Fatty Acids in Pigs and Omega-3 Polyunsaturated Fatty Acid-Enriched Pork: A Review. Livest. Sci. 2021, 243, 104370. [CrossRef]

72. Wood, J.D.; Richardson, R.I.; Nute, G.R.; Fisher, A.V.; Campo, M.M.; Kasapidou, E.; Sheard, P.R.; Enser, M. Effects of Fatty Acids on Meat Quality: A Review. Meat Sci. 2004, 66, 21-32. [CrossRef]

73. Kouakou, N.D.V.; Grongnet, J.-F.; Assidjo, N.E.; Thys, E.; Marnet, P.-G.; Catheline, D.; Legrand, P.; Kouba, M. Effect of a Supplementation of Euphorbia Heterophylla on Nutritional Meat Quality of Guinea Pig (Cavia Porcellus L.). Meat Sci. 2013, 93, 821-826. [CrossRef]

74. Mamani-Linares, L.W.; Gallo, C.B. Meat Quality, Proximate Composition and Muscle Fatty Acid Profile of Young Llamas (Lama Glama) Supplemented with Hay or Concentrate during the Dry Season. Meat Sci. 2014, 96, 394-399. [CrossRef]

75. Altmann, B.A.; Wigger, R.; Ciulu, M.; Mörlein, D. The Effect of Insect or Microalga Alternative Protein Feeds on Broiler Meat Quality. J. Sci. Food Agric. 2020, 100, 4292-4302. [CrossRef]

76. de Souza Vilela, J.; Alvarenga, T.I.R.C.; Andrew, N.R.; McPhee, M.; Kolakshyapati, M.; Hopkins, D.L.; Ruhnke, I. Technological Quality, Amino Acid and Fatty Acid Profile of Broiler Meat Enhanced by Dietary Inclusion of Black Soldier Fly Larvae. Foods 2021, 10, 297. [CrossRef]

77. Gariglio, M.; Dabbou, S.; Gai, F.; Trocino, A.; Xiccato, G.; Holodova, M.; Gresakova, L.; Nery, J.; Bellezza Oddon, S.; Biasato, I.; et al. Black Soldier Fly Larva in Muscovy Duck Diets: Effects on Duck Growth, Carcass Property, and Meat Quality. Poult. Sci. 2021, 100, 101303. [CrossRef]

78. Barroso, F.G.; Sánchez-Muros, M.-J.; Segura, M.; Morote, E.; Torres, A.; Ramos, R.; Guil, J.-L. Insects as Food: Enrichment of Larvae of Hermetia Illucens with Omega 3 Fatty Acids by Means of Dietary Modifications. J. Food Compos. Anal. 2017, 62, 8-13. [CrossRef] 
79. Hoc, B.; Genva, M.; Fauconnier, M.-L.; Lognay, G.; Francis, F.; Caparros Megido, R. About Lipid Metabolism in Hermetia Illucens (L. 1758): On the Origin of Fatty Acids in Prepupae. Sci. Rep. 2020, 10, 11916. [CrossRef] [PubMed]

80. Truzzi, C.; Giorgini, E.; Annibaldi, A.; Antonucci, M.; Illuminati, S.; Scarponi, G.; Riolo, P.; Isidoro, N.; Conti, C.; Zarantoniello, M.; et al. Fatty Acids Profile of Black Soldier Fly (Hermetia Illucens): Influence of Feeding Substrate Based on Coffee-Waste Silverskin Enriched with Microalgae. Anim. Feed Sci. Technol. 2020, 259, 114309. [CrossRef] 